\title{
Application of Ionic Liquids in Biocatalysis
}

\author{
Maja Habulin, Mateja Primožič and Željko Knez \\ University of Maribor, Faculty of Chemistry and Chemical Engineering \\ Slovenia
}

\section{Introduction}

Biotransformations have been of enormous economic and social importance throughout the history of mankind (Liese et al., 2000). Biocatalysis may be the most efficient way of producing fine chemicals. Today, several chemicals like pharmaceuticals, amino acids, saccharides and polysaccharides, esters and vitamins are produced by enzymatic biotransformations on industrial scale (Liese et al., 2000).

The production of fine chemicals results in output of considerable volume of waste. Most of wastes are solvents such as water, volatile organic compounds (VOCs) etc. Solvents comprise $2 / 3$ of all industrial emissions and $1 / 3$ of all VOC emissions nationwide. These emissions have been linked to a host of negative effects (global climate change, pollution of air, human illness etc.) (Brennecke \& Maginn, 2001). In recent years, green chemistry is become a growing area of research. Therefore the search for new environmental friendly and benign solvents and catalysts which can be easily recycled or reused is of significant interest. The ideal solvent should be chemically and physically stabile, recyclable, and reusable, should have a very low volatility, should allow selective and rapid transformations and should be easy to handle.

For the biocatalysis, there are five main "green" solvent systems: supercritical fluids (SCFs), fluorinated solvents, ionic liquids (ILs), water, and solvent free reactions (Hobbs \& Thomas, 2007). Enzymatic reactions could be performed under preferred conditions with minimized yield of the undesired by-products. Meanwhile, low yields, selectivity, and poor solubility of substrates in aqueous medium may require the enzymatic reactions to be carried out in non-aqueous medium (Sureshkumar \& Lee, 2009).

SCF is any substance at a temperature and pressure above its critical point. Close to the critical point, small changes in pressure or temperature result in large changes in density, allowing many properties of a SCF to be "fine-tuned" (Jessop \& Leitner, 1999). There are several advantages using the SCFs as solvents in chemical synthesis, where all are based on unique thermo-physical properties of SCFs for their mixtures with reactants. The main advantage of biocatalysis in SCFs is the tunability of the properties of the solvent by changes in the pressure and/or the temperature. The application of SCFs enables also design of integrated reaction and separation processes. In mass transfer limited processes the reaction rate can be increased if SCFs are applied due to higher diffusivity and to reduce viscosity of reaction system. SCFs display unique substrate specificity at relative mild reaction conditions. 
Environmental benefits of most SCFs in industrial processes are in replacement of environmentally far more damaging conventional organic solvents. An environmental impact is also low energy consumption during operation. Health and safety benefits include the fact that the most important SCFs (supercritical carbon dioxide $\left(\mathrm{SC} \mathrm{CO}_{2}\right)$ and supercritical water $\left(\mathrm{SC}_{2} \mathrm{O}\right)$ ) are non-cancerogenic, non-mutagenic, non-flammable, nontoxic, and thermodynamically stable. $\mathrm{SC} \mathrm{H}_{2} \mathrm{O}$ however cannot be used as medium for biocatalytic reactions because of the high temperatures involved which completely deactivate the enzymes.

Since the first reports on the use of SCFs (Randolph et al., 1985), as reaction media for enzyme-catalyzed reaction several reviews regarding biocatalysis in SCFs have been published (Knez \& Habulin, 2002; Habulin et al., 2007a; Knez, 2009; Hobbs \& Thomas, 2007; Mesiano et al., 1999; Krishna, 2002; Matsuda et al., 2005). Majority of these biocatalytic reactions have been carried out in $\mathrm{SC} \mathrm{CO}_{2}$.

Enzymes in SCFs could be used in their native form (powder, liquid, whole cells ...) or immobilized on a carrier (resin, sol-gel matrix ...). Enzymes, apart from their form, are not soluble in $\mathrm{CO}_{2}$. Therefore, biocatalysis in $\mathrm{SC} \mathrm{CO}_{2}$ is always heterogeneous.

In SCFs there are both the direct effects of pressure on enzyme activity which may lead to denaturation, and the indirect effects of pressure on enzymatic activity and selectivity. In the case of $\mathrm{SC} \mathrm{CO}_{2}$ direct effect of pressure on enzyme inactivation is small and the protein structure is expected to be retained on the whole and only local changes may occur. Those local changes may lead to another active state of a protein, which may possess an altered activity, specificity or stability. Pressure is also likely to have an indirect affect on the efficiency of the reaction by changing either the rate constant or the solubility of the reactants. At high pressures solute-solvent interactions increase, resulting in a higher solvent capacity (Habulin \& Knez, 2001). However, it has also disadvantages, as sometimes lower catalytic activities in the solvent which have been attributed to the formation of carbonic acid (Habulin et al., 2007a).

Ionic liquids (ILs) are organic salts consisting of ions, which exist in the liquid state at ambient temperatures. In the last 15 years, ILs were recognized as a novel class of solvents for chemical processes. They represent also an exciting new class of reaction solvents for catalysis, which have been used successfully for enzyme-catalyzed reactions (Moniruzzaman et al., 2010; van Rantwijk \& Sheldon, 2007; Kragl et al., 2002).

Common ions involved in ILs for biocatalysis are: cations, which are generally bulky, organic with low symmetry, e.g. derivatives of imidazolium, pyridinium, pyrrolidinium, ammonium, sulfonium, phosphonium, ..., and anions, which are either organic or inorganic and can be classified in two classes: a.) those which give polynuclear anions, such as $\left[\mathrm{Al}_{2} \mathrm{Cl}_{7}\right]^{-},\left[\mathrm{Al}_{3} \mathrm{Cl}_{10}\right]^{-},\left[\mathrm{Au}_{2} \mathrm{Cl}_{7}\right]^{-}, \ldots$, and b.) those that corresponds to mononuclear anions which lead to neutral, stoichiometric ILs, such as tetrafluoroborate, hexafluorophosphate, bis[(trifluoromethyl)sulfonyl]amide, nitrate, trifluoroacetate, methyl-sulfate etc. (OlivierBourbigou \& Magna 2002).

ILs combine good and tunable solubility properties with no measurable vapour pressure and excellent thermal stabilities. They have rapidly found a place of choice as valuable environmentally benign reaction and separation media. The possible choices of cation and anion that will result in the formation of ILs with different physico-chemical properties are numerous (Brennecke \& Maginn, 2001). Furthermore, ILs are compounds which have a potential to be recycled and reused. They provide a medium for performing clean reactions with minimum waste generation. 
ILs showed an over-stabilization effect in biocatalysts on the basis of the double role played by these neoteric solvents. First, ILs act as solvents, providing an adequate microenvironment for the catalytic action of the enzyme (mass transfer phenomena and active catalytic conformation); second, ILs may be regarded as liquid immobilization supports, since multipoint enzyme-IL interactions (hydrogen, Van der Waals, ionic, etc.) may occur, resulting in a flexible supramolecular net able to maintain active the protein conformation (De Diego et al., 2005). However, many enzymes were rapidly inactivated in ILs. Some of them remain stable and catalytically active in ILs, even though they are not stable and active in polar organic solvents.

The disadvantages of using ILs as media for enzymatic reactions are their high costs which could present limitation for their application to products of high added value. The question about how "green" are ILs, also appears, since their synthesis involves toxic reagents. The toxicity effect on humans/environment is still not yet clear, so they are rather considered as harmful. For enzyme-catalyzed reactions, ILs can be used as co-solvents in aqueous phase, as two-phase systems together with other solvents and as pure solvents.

One of the problems with the use of ILs for synthesis is the extraction of products. Volatile products could be separated by distillation; on the other hand, the non-volatile products could be separated by solvent extraction with the solvent which is immiscible with the ILs and is environmentally friendly (e.g. $\mathrm{SC} \mathrm{CO}_{2}$ ).

The volatile and nonpolar $\mathrm{SC} \mathrm{CO}_{2}$ forms different two-phase systems with nonvolatile and polar ILs. The product recovery process with these systems is based on the principle that SC $\mathrm{CO}_{2}$ is soluble in ILs, but ILs are not soluble in $\mathrm{SC} \mathrm{CO}_{2}$ (Blanchard et al., 2001). Since most of the organic compounds are soluble in $\mathrm{SC} \mathrm{CO}_{2}$, with the high solubility of $\mathrm{SC} \mathrm{CO}_{2}$ in ILs, these products are transferred from the IL to the supercritical phase (Blanchard \& Brennecke, 2001).

Recent researches have demonstrated the possibility to carry out integral green biocatalytic processes by combining SC $\mathrm{CO}_{2}$ and ILs with enzymes (Lozano et al., 2003; Lozano et al., 2004; Lozano et al., 2007a; Miyawaki \& Tatsuno, 2008; Knez, 2009; Fan \& Qian, 2010), because their different miscibilities produce the two-phase systems that show an exceptional ability to carry out both the biotransformation and the products extraction steps simultaneously.

In our studies, ILs were used as reaction media for lipase-catalyzed kinetic resolution of $(R, S)-1$-phenylethanol with vinyl acetate. Transesterification of chiral substrate, $(R, S)-1$ phenylethanol with vinyl acetate, was performed in different ILs at atmospheric pressure and in $\mathrm{SC} \mathrm{CO}_{2} / \mathrm{IL}$ biphasic system. Influence of different parameters such as concentration of IL, type of IL on conversion or reaction rate of transesterification were studied. Next, stability of immobilized Candida antarctica lipase B (CALB) in selected IL was tested.

\section{An overview of biocatalysis in ILs and in SCFs/ILs systems}

In the last two decades much research has been done in the field of biocatalysis in ILs. The reason for the rapid increase of performing biotransformations in ILs was in the ability of presenting excellent enzyme activity, stability and selectivity (Yang \& Pan, 2005; van Rantwijk \& Sheldon, 2007). Additionally, ILs could be "taylor-made" for a specific reaction, simply by selecting appropriate combinations of cations and anions. Probably this is the major attraction of making ILs an alternative to conventional organic solvents. However, the range of ILs suitable for biocatalytic whole-cell applications is still limited and the influence 
of different anion and cation groups has been investigated by Bräutigam et al. (Bräutigam et al., 2009). The applicability of ionic liquids for their use as second liquid phase in whole-cell biotransformations was evaluated in combination with a recombinant Escherichia coli coexpressing a Lactobacillus brevis alcohol dehydrogenase gene for the desired asymmetric reduction of prochiral ketones and a Candida boidinii formate dehydrogenase for the regeneration of $\mathrm{NAD}^{+}$with formate. Ionic liquids, 1-(2-hydroxyethyl)-3-methylimidazolium bis(trifluoromethylsulfonyl)imide $\quad\left(\left[\left(\mathrm{E}_{2} \mathrm{OH}\right) \mathrm{mim}\right][\mathrm{NTF}]\right)$ and $\mathrm{N}$-(3-hydroxypropyl)pyridinium bis(trifluoromethylsulfonyl)imide $\left(\left[\left(\mathrm{P}_{3} \mathrm{OH}\right) \mathrm{PYR}\right][\mathrm{NTF}]\right)$, seem to be toxic to the whole-cell biocatalyst and therefore they are not suited for an application. They resulted in yields below $3 \%$ after a process time of $1 \mathrm{~h}$. Furthermore, it was validated that ionic liquids with hexafluorophosphate $\left(\left[\mathrm{PF}_{6}\right]^{-}\right)$and bis(trifluoromethylsulfonyl)imide ([NTF $\left.]^{-}\right)$anions are better qualified than corresponding ILs with tris(perfluoroalkyl)trifluorophosphate $\left([\mathrm{FAP}]^{-}\right)$anion. Consequently, they should be preferred for biphasic biotransformations.

Four types of whole-cell biocatalysts: wild-type Rhizopus oryzae producing triacylglycerol lipase (w-ROL), recombinant Aspergillus oryzae expressing Fusarium heterosporum lipase (rFHL), C. antarctica lipase B (r-CALB), and mono- and diacylglycerol lipase from A. oryzae ( $\mathrm{r}-$ mdlB) were used to catalyze methanolysis of soybean oil in the presence of ILs. w-ROL gave very high yield of fatty acid methyl ester (ME) in ionic liquid 1-ethyl-3-methylimidazolium tetrafluoroborate $\left([\mathrm{emim}]\left[\mathrm{BF}_{4}\right]\right)$ or 1-butyl-3-methylimidazolium tetrafluoroborate ([bmim] $\left[\mathrm{BF}_{4}\right]$ ) biphasic systems following a $24 \mathrm{~h}$ reaction (Arai et al., 2010).

Numerous types of enzymatic reactions (Habulin et al., 2007b; Contesini \& Carvalho, 2006; Lou et al., 2006; Tan et al., 2007; Hernandez-Fernandez et al., 2007) have been carried out using ILs as solvents with similar or enhanced reaction rates and enzyme activities, and with higher operational stabilities and enantioselectivities compared to those observed in organic solvents (Welton, 1999; van Rantwijk et al., 2003; Kragl et al., 2002).

Esterification of glycerol to sinapic acid (SA) in anion $\left[\mathrm{PF}_{6}\right]^{-}$-containing ILs, using a feruloyl esterase (FAE) from Aspergillus niger (AnFaeA) as biocatalyst was investigated. Hydrophobic anion $\left(\left[\mathrm{PF}_{6}\right]^{-}\right)$-containing ILs were found to be appropriate reaction media for the enzymatic esterification of glycerol to SA, especially when they possess hydrophilic cations (1-[2-(2-methoxyethoxy)-ethyl]-3-methyl-imidazolium cation - $\left[\mathrm{C}_{5} \mathrm{O}_{2} \mathrm{mim}\right]^{+}, 1-(2-$ hydroxyethyl)-3-methyl-imidazolium cation - $\left[\mathrm{C}_{2} \mathrm{OHmim}\right]^{+}$) (Vafiadi et al., 2009).

Lipases, noted for their tolerance of organic solvents, are obvious candidates for the enzymatic synthesis in ILs (Sureshkumar \& Lee, 2009). Kurata et al. (Kurata et al., 2010) described a transesterification reaction of methyl caffeate with various alcohols to produce caffeic acid phenethyl ester (CAPE) analogues with a lipase using an IL as the reaction medium. Effect of ILs on immobilized lipase B from Candida antarctica - CALB (Novozyme 435) showed that the anion nature is a crucial factor in determining enzyme activity. It was reported that the hydrogen-bond basicities of $\left[\mathrm{bmim}_{[}\left[\mathrm{BF}_{4}\right]\right.$ and 1-butyl-3methylimidazolium trifluoromethanesulfonate $\left([\mathrm{bmim}]\left[\mathrm{CF}_{3} \mathrm{SO}_{3}\right]\right)$ are larger than those of 1butyl-3-methylimidazolium bis(trifluoromethylsulfonyl)imide ([bmim][NTf $\left.f_{2}\right]$ ) and 1-butyl3-methylimidazolium hexafluorofosfate ([bmim] $\left[\mathrm{PF}_{6}\right]$ ) (Anderson et al., 2002; Kaar et al., 2003). Additionally, it was suggested that the $\left[\mathrm{BF}_{4}\right]^{-}$and $\left[\mathrm{CF}_{3} \mathrm{SO}_{3}\right]^{-}$anions are more nucleophilic than the $\left[\mathrm{NTf}_{2}\right]^{-}$and $\left[\mathrm{PF}_{6}\right]^{-}$anions, and the $\left[\mathrm{BF}_{4}\right]^{-}$and $\left[\mathrm{CF}_{3} \mathrm{SO}_{3}\right]^{-}$anions coordinate more strongly to positively charged sites in the structure of an enzyme.

The immobilized CALB showed excellent storage stability and reusability in $\left[\mathrm{PF}_{6}\right]^{-}$ containing ionic liquids. On account of high enzyme stability and high solubility of product versus substrate, $\left[\mathrm{PF}_{6}\right]^{-}$containing ionic liquids enabled the synthesis of various lipophilic 
derivatives of hydroxycinnamic acid derivatives, such as ferulic acid, with higher conversions and reaction rates than the corresponding $\left[\mathrm{BF}_{4}\right]^{-}$containing ionic liquids and commonly used organic solvents (Katsoura et al., 2009).

Seventeen types of ILs were screened to test their performance as media to host lipasecatalyzed glycerolysis. It turned out that the reaction rate, triglyceride (TG) conversion, yield of diglyceride (DG), and by-product minimization depended greatly on the structure and property of the ILs applied. The reactions in trioctylmethylammonium bis(trifluoromethylsulphonyl)imide ([toma][ $\left.\mathrm{NTf}_{2}\right]$ ) and Ammoeng 120 can produce comparable DG yield with those typical conventional solvent systems, but with less byproducts (Kahveci et al., 2009).

One reaction system which could greatly benefit from an increased capacity in ILs is the acylation reaction of flavonoids. Flavonoids are naturally occurring bioactive compounds whose application in the food, pharmaceutical and even cosmetics industries could be drastically expanded through improved solubility and miscibility in hydrophobic environments (Lue et al., 2010).

However, there is no "best" ionic liquid for performing biotransformation just as there is no "best" organic solvent in general for carrying out biocatalysis (Vidya \& Chadha, 2010).

The main problem associated with the use of ILs as reaction media for biotransformations is the recovery of products from the reaction mixture and recycling of the catalyst (Sheldon, 2005; Blanchard \& Brennecke, 2001).

Several techniques of separation and product recovery from ILs exist. An attractive solution is the use $\mathrm{SC} \mathrm{CO}_{2}$ as extraction solvent, whereby the catalyst remains in the IL phase and the product is extracted into the $\mathrm{SC} \mathrm{CO}_{2}$ phase (Sheldon, 2005). Blanchard's group demonstrated the recovery of organic products from ILs by using $\mathrm{SC} \mathrm{CO}_{2}$. They have shown that a wide variety of solutes (alcohols, amides, ketones) can be extracted from [bmim] $\left[\mathrm{PF}_{6}\right]$ with $\mathrm{CO}_{2}$ with recovery rates greater than $95 \%$ and without any IL contamination (Blanchard \& Brennecke, 2001).

ILs can absorb large quantities of $\mathrm{CO}_{2}$ at low pressure $(0.6 \mathrm{~mol}$ fraction at $10 \mathrm{MPa})$, although the amount of IL dissolved in $\mathrm{CO}_{2}$ is negligible. This fact not only shows the exceptional ability of $\mathrm{SC} \mathrm{CO}_{2}$ to extract a wide variety of hydrophophic compounds from ILs, but also decreases the viscosity of ILs, thus, improving the mass-transfer phenomena (Lozano et al., 2007b).

Applying enzymes in $\mathrm{SC} \mathrm{CO}_{2} / \mathrm{ILs}$ biphasic systems has a very short history. The first successful biotransformation in SC CO 2 /ILs biphasic systems was reported in the year 2002 (Lozano et al., 2002). The protective effect of ILs towards enzyme deactivation by temperature or $\mathrm{CO}_{2}$ was demonstrated by the observed increase in synthetic activity of the enzyme when it was assayed in the presence of IL. Studies based on enzymatic kinetic resolution of rac-1-phenylethanol with vinyl propionate performed in $\mathrm{SC} \mathrm{CO}_{2} / \mathrm{ILs}$ biphasic systems have been reported (Lozano et al., 2006; Lozano et al., 2003). Both free and immobilized CALB were able to catalyze specifically the synthesis of $(R)-1$-phenylethyl propionate in SC $\mathrm{CO}_{2} / \mathrm{ILs}$ biphasic systems, and excellent activity, stability and enantioselectivity levels were recorded. The suitability of CALB to catalyze the stereoselective transesterification of $(R)$-1-phenylethanol from the racemic mixture has been widely demonstrated (Lozano et al., 2004; Lozano et al., 2003; Eckstein et al., 2002; Suan \& Sarmidi, 2004).

When continuous dynamic kinetic resolution (DKR) was performed in $\mathrm{SC} \mathrm{CO}_{2} / \mathrm{IL}$ biphasic media with simultaneous presence of immobilized CALB the improvement of DKR process was observed. The formation of undesired (S)-1-phenylethyl propionate was obtained in 
low levels, which could be related to increased mass-transfer limitations for substrates and products in $\mathrm{SC} \mathrm{CO}_{2}$. A commercial solution of free CALB (Novozym 525L) was immobilized onto 12 different silica supports modified with specific side chains, which were assayed for the kinetic resolution of rac-1-phenylethanol in both IL/hexane and $\mathrm{SC} \mathrm{CO}_{2} / \mathrm{IL}$ biphasic media (Lozano, et al., 2007b). Immobilized derivatives coated with ILs [toma] $\left[\mathrm{NTf}_{2}\right.$ ] and butyl-trimethylammonium bis(trifluoromethylsulfonyl)imide ([btma][ $\left.\mathrm{NTf}_{2}\right]$ ) improved the synthetic activity of the enzyme in $\mathrm{SC} \mathrm{CO}_{2}$ by up to 6 times with respect to the hexane medium. This could be due to the excellent ability of $\mathrm{SC} \mathrm{CO}_{2}$ to transport dissolved solutes through the IL phase, which improves the transfer rate of substrates to the enzyme microenvironment compared with the liquid systems. Next, the suitability of two different ILs based on quarternary ammonium cations associated with the same anion (bis(trifluoromethane)sulfonyl amide $\left[\mathrm{NTf}_{2}\right]$ ) for CALB-catalyzed ester synthesis in SC $\mathrm{CO}_{2}$ /IL biphasic system was studied (Lozano et al., 2004). The efficiency of the system was depended on both the mass-transfer phenomena between ILs and $\mathrm{SC} \mathrm{CO}_{2}$ immiscible phases and the specificity of the enzyme toward the catalyzed reaction. At lipase-catalyzed kinetic resolution of rac-1-phenylethanol with vinyl acetate in 1-butyl-3-methylimidazolium bis(trifluoromethylsulfonyl)amide ([bmim] [bta]) using $\mathrm{SC} \mathrm{CO}_{2}$ in a batch-wise process the enzyme fully retained its activity and the enantiomeric discrimination remained uniformly high (Reetz et al., 2002). Garcia et al. (Garcia et al., 2004) explored the catalytic activities of Fusarium solani pisi cutinase immobilized on zeolite NaY and CALB immobilized on an acrylic resin (Novozym 435) for the transesterification reaction of rac-2-phenyl-1-propanol with vinyl butyrate in $\mathrm{SC} \mathrm{CO}_{2} /\left[\mathrm{bmim}_{[}\right]\left[\mathrm{PF}_{6}\right]$ biphasic system. Although the enantioselectivity of enzymes, cutinase and lipase, towards rac-2-phenyl-1-propanol at all the reaction conditions tested was found to be low, the reaction rates, observed in the SC $\mathrm{CO}_{2} /[\mathrm{bmim}]\left[\mathrm{PF}_{6}\right]$ biphasic system, were much higher than for the $[\mathrm{bmim}]\left[\mathrm{PF}_{6}\right]$ on its own. Hernández et al. and de los Rios et al. (Hernández et al., 2006; de los Rios et al., 2007) successfully applied the dynamic membranes with immobilized CALB for butyl propionate synthesis in a recirculating bioreactor in supercritical medium and in $\mathrm{SC} \mathrm{CO}_{2} / \mathrm{IL}$ biphasic systems at $50{ }^{\circ} \mathrm{C}$ and $8 \mathrm{MPa}$. In SC CO $2 / \mathrm{IL}$ systems, the immobilized enzyme coated with different ILs ([bmim] $\left[\mathrm{NTf}_{2}\right],[\mathrm{bmim}]\left[\mathrm{PF}_{6}\right]$, 1-octyl-3-methylimidazolium hexafluorophosphate - $[\mathrm{omim}]\left[\mathrm{PF}_{6}\right]$ and 1-butyl-2,3-dimethylimidazolium - [bdmim] $\left.\left[\mathrm{PF}_{6}\right]\right)$, showed an increase in the selectivity of the process compared with $\mathrm{SC} \mathrm{CO}_{2}$ assayed in the absence of IL. The influence of different co-solvents, such as ethyl methylketone, $n$-heptane, 2-methyl-2butanol, acetone, $[\mathrm{bmim}]\left[\mathrm{PF}_{6}\right]$ and $[\mathrm{bmim}]\left[\mathrm{BF}_{4}\right]$, on citronellol laurate synthesis in $\mathrm{SC} \mathrm{CO}_{2}$ at $60{ }^{\circ} \mathrm{C}$ and $10 \mathrm{MPa}$ in a high-pressure batch stirred-tank reactor was studied (Habulin et al., $2007 \mathrm{~b}$ ). Low ester concentration was obtained in hydrophilic IL [bmim] $\left[\mathrm{BF}_{4}\right]$, which could be due to desorption of water from the enzyme surface and therefore decrease in the activity of the enzyme occurred. On the contrary, $[b \operatorname{mim}]\left[\mathrm{PF}_{6}\right]$ is a hydrophobic solvent in which higher ester concentration was obtained compared with $[\mathrm{bmim}]\left[\mathrm{BF}_{4}\right]$.

Miyawaki and Tatsuno (Miyawaki \& Tatsuno, 2008) studied lipase-catalyzed butanolysis of triolein in an IL methyltrioctylammonium trifluoroacetate ([mtoa][tfa]) and afterwards the product, butyloleate, was selectively extracted from the reaction mixture using $\mathrm{SC} \mathrm{CO}_{2}$ at 35 ${ }^{\circ} \mathrm{C}$ and 8.6 MPa. Although a small amount of IL added seemed inhibitory, a large amount of added IL accelerated the reaction.

Enantiomerically pure alcohols are useful building blocks and chiral auxiliaries for the synthesis of bioactive compounds such as pharmaceuticals, agrochemicals and natural products (Faber, 2000). Recently, a number of microorganisms with lipase activity have been 
reported for the stereoselective transesterification of racemic-1-phenyl ethanol (Goswami \& Goswqami, 2005); e.g. soil isolated bacterial strain Pseudomonas aeruginosa catalyses the enantioselective transesterification of 1-phenyl ethanol and its various derivatives with absolute enantioselectivity (Singh et al., 2010).

Paljevac et al. (Paljevac et al., 2009) successfully applied immobilized CALB as chiral biocatalyst for enzyme-catalyzed transesterification of $(R, S)-1$-phenylethanol in $\mathrm{SC} \mathrm{CO}_{2}$ and in SC CO $2 /$ IL two-phase system. An increase in the conversion and in the reaction rate was observed as the temperature and pressure were increased from $40^{\circ} \mathrm{C}$ to $80^{\circ} \mathrm{C}$ and from 8 $\mathrm{MPa}$ to $10 \mathrm{MPa}$, respectively.

Lipase-catalyzed acylation (kinetic resolution) of chiral substrate, $(R, S)$-1-phenylethanol with vinyl acetate, was performed in ILs as reaction media. Transesterification of chiral substrate, $(R, S)$-1-phenylethanol with vinyl acetate was also performed in SC $\mathrm{CO}_{2} / \mathrm{IL}$ biphasic media and was compared with the same reaction, performed at atmospheric pressure. ILs based on the $N, N$-dialkylimidazolium cation were due to the wide spectrum of physico-chemical properties of this class chosen as model reaction media. The reaction was catalyzed by immobilized CALB (Novozym 435).

A comparison of reactions performances obtained in [emim] $\left[\mathrm{NTf}_{2}\right]$ with those obtained in ILs based on dialkylimidazolium cations associated with mononuclear anions, such as $\left[\mathrm{BF}_{4}\right]^{-}$ and $\left[\mathrm{PF}_{6}\right]^{-}$, was proposed.

\section{Materials and methods}

\subsection{Enzymes and chemicals}

Immobilized CALB (Novozym 435) was kindly donated from Novozymes (Bagsvaerd, Denmark). (R)-1-phenylethanol and (S)-1-phenylethanol were supplied from Sigma-Aldrich (Saint Louis, USA). Vinyl acetate ( $\geq 99 \%),(R, S)$-1-phenylethanol ( $\geq 98 \%)$, 1-ethyl-3-methylimidazolium bromide ( $\geq 97 \%$ ), and $65 \%$ (gravimetric) hexafluoro-phosphoric acid solution in water were supplied from Fluka (Buchs, Switzerland). Acetone ( $\geq 99.8 \%), n$-heptane $(\geq 99$ $\%)$, anhydrous magnesium sulfate ( $\geq 98 \%)$, 1-chlorobutane $(\geq 99 \%)$, dichloromethane $(\geq 99.8$ $\%)$, ethyl acetate ( $\geq 99.5 \%)$, and 1-methylimidazole ( $\geq 99 \%)$ were purchased from Merck (Darmstadt, Germany). Decane - Reagent Plus ${ }^{\circledR}(\geq 99 \%)$, N-lithiotrifluoromethanesulfonimide $(97 \%)$ and sodium tetra-fluoroborate $(98 \%)$ were provided by Aldrich Chemical Co. (Diesenhofen, Germany). Carbon dioxide 2.5 was provided by Messer MG (Ruše, Slovenia). Helium 6.0 was supplied from Linde plin (Celje, Slovenia).

\subsection{Synthesis of ionic liquids}

\subsubsection{1-Butyl-3-methylimidazolium chloride [bmim][Cl]}

The ionic liquid [bmim][Cl] was synthesized using 1-methylimidazole and 1-chlorobutane. The reaction mixture was stirred at $60{ }^{\circ} \mathrm{C}$ for $70 \mathrm{~h}$ in round-bottomed flask fitted with a reflux condenser. Obtained yellow, viscous liquid mixture was cooled to room temperature, washed three times with ethyl acetate portions and the formatted crystals of [bmim] $\mathrm{Cl}]$ were dried under vacuum at $60^{\circ} \mathrm{C}$ for $24 \mathrm{~h}$ (Lewandowski \& Galiński, 2004). Acquired ionic liquid served as basic component for synthesis of $[\mathrm{bmim}]\left[\mathrm{BF}_{4}\right]$ and $[\mathrm{bmim}]\left[\mathrm{PF}_{6}\right]$.

\subsubsection{1-Butyl-3-methylimidazolium tetrafluoroborate [bmim][BF $]$}

The sodium tetrafluoroborate was added to a solution of $[\mathrm{bmim}][\mathrm{Cl}]$ in acetone. The reaction mixture was stirred at room temperature for $24 \mathrm{~h}$. After stirring, the reaction mixture was 
filtered through a plug of celite to remove the formed sodium chloride crystals. The solvent was evaporated from hydrophilic ionic liquid [bmim] $\left[\mathrm{BF}_{4}\right]$ at $40{ }^{\circ} \mathrm{C}$ for $24 \mathrm{~h}$ (Lozano et al., 2001). Initial water content in the synthesized $[\mathrm{bmim}]\left[\mathrm{BF}_{4}\right]$ was $0.18 \%(\mathrm{w} / \mathrm{w})$.

\subsubsection{1-Butyl-3-methylimidazolium hexafluorofosfate [bmim][PF}

An aqueous solution of hexafluorophosphoric acid was slowly added to a solution of $[\mathrm{bmim}][\mathrm{Cl}]$ in water and stirred at room temperature for $36 \mathrm{~h}$. The two-phase system was separated, and the lower phase $\left([\mathrm{bmim}]\left[\mathrm{PF}_{6}\right]\right)$ was washed with water portions until the neutral $\mathrm{pH}$ value. The light yellow [bmim] $\left[\mathrm{PF}_{6}\right]$ was dried under vacuum at $80{ }^{\circ} \mathrm{C}$ for $24 \mathrm{~h}$ (Lewandowski \& Galiński, 2004). Initial water content in the synthesized [bmim] $\left[\mathrm{PF}_{6}\right]$ was $0.04 \%(w / w)$.

\subsubsection{1-Ethyl-3-methylimidazolium bis[(trifluoromethyl)sulfonil]amide [emim][NTf}

1-Ethyl-3-methylimidazolium bromide and $N$-lithiotrifluoro-methanesulfonimide were mixed in hot water for $1 \mathrm{~h}$. The ionic liquid [emim] $\left[\mathrm{NTf}_{2}\right]$ was extracted with dichloromethane, and dried under vacuum at $100{ }^{\circ} \mathrm{C}$ for $24 \mathrm{~h}$ (Lozano et al., 2001). Initial water content in the synthesized [emim] $\left[\mathrm{NTf}_{2}\right]$ was $0.17 \%(\mathrm{w} / \mathrm{w})$.

\subsection{Enzyme-catalyzed transesterification of $(R, S)$-1-phenylethanol performed in a batch stirred tank reactor at atmospheric pressure in IL}

Enantiomerically pure compound (R)-1-phenylethyl acetate production by enzymatic transesterification reaction of $(R, S)-1$-phenylethanol with vinyl acetate as acyl donor was performed. Reaction, catalyzed with immobilized CALB, was performed in a batch stirredtank reactor (Knez \& Habulin, 1992). (R,S)-1-Phenylethanol and vinyl acetate were dissolved in ionic liquid, which was used as a reaction medium. The reactor filled up with substrates, was immersed in a water bath, heated to the desired operating temperature and stirred with a magnetic stirrer. The reaction was started by addition of CALB. Aliquots of the sample were periodically withdrawn from the reaction mixture at fixed time intervals, suspended in $0.2 \%$ solution of decane (internal standard, IS) in $n$-heptane. Resulting solution was analyzed by gas chromatography. At least two replicates of experiments were carried out at each operative condition.

\subsection{Enzyme-catalyzed transesterification of $(R, S)-1$-phenylethanol performed in a high-pressure variable-volume view cell in two-phase system $\mathrm{SC} \mathrm{CO}_{2} / \mathrm{IL}$}

CALB-catalyzed transesterification of $(R, S)$-1-phenylethanol with vinyl acetate in two-phase system $\mathrm{SC} \mathrm{CO}_{2} / \mathrm{IL}$ was performed in a high-pressure variable-volume view cell equipped with stirrer and with two stainless steel cartridge heaters to heat the reaction mixture (Fig. 1). The cell with tunable internal volume between 30 to $60 \mathrm{~cm}^{3}$ was designed to operate up to $75 \mathrm{MPa}$ and $200{ }^{\circ} \mathrm{C}$. First, the bioreactor was loaded with immobilized CALB and heated to the desired operating temperature. Next, the substrates, $(R, S)-1$-phenylethanol, vinyl acetate, and certain amount of IL were added into the bioreactor. The mass ratio between loaded biocatalyst and substrate was 11.1. Additionally, liquid $\mathrm{CO}_{2}$ was pumped into the reactor up to the working pressure. The reaction was started when selected pressure was achieved and mixing of reaction mixture was turned on. Transfer of substrates from upper phase through IL to active sites of biocatalyst, where the reaction took place, and transfer of

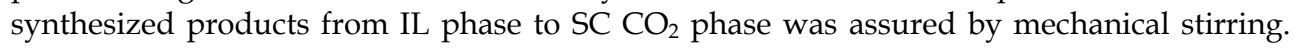


During the reaction, samples of reaction mixture were withdrawn from upper phase to monitor the product evolution. Aliquots of reaction mixture were suspended in $0.2 \%$ solution of decane (internal standard, IS) in $n$-heptane. The enantimers concentrations during the reaction were monitored using gas chromatography. At least two replicates of experiments were carried out at each operative condition.

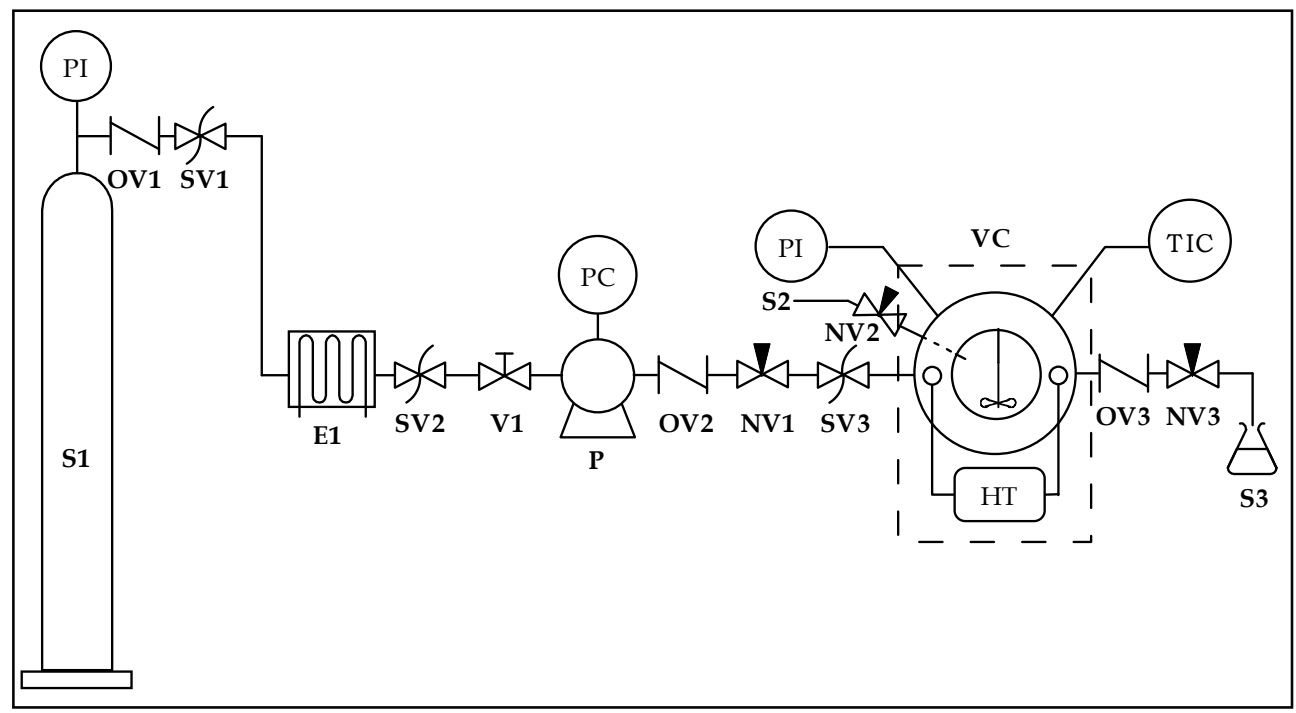

Fig. 1. High-pressure variable-volume view cell: $\mathrm{S} 1$ - $\mathrm{CO}_{2}$ cylinder; $\mathrm{E} 1$ - cooler; $\mathrm{P}$ - highpressure membrane pump; VC - variable-volume view cell with mixer; HT - electrical heater; PI - pressure indicator; PC - pressure controller; TIC - temperature indicator and controller; OV1, OV2, OV3 - high-pressure one-way valves; SV1, SV2, SV3 - high-pressure safety valves; NV1, NV2, NV3 - high-pressure needle valves; V1 - high-pressure valves; S2 liquid charge; and S3 - sample collector.

\subsection{Gas chromatography analysis (GC analysis)}

Enantiomers content during the reaction was monitored using an HP 5890 series A gas chromatograph equipped with a flame-ionisation detector (FID), using a $\beta$-cyclodextrin capillary column $(\beta$-DEX 120) with the dimension length $\times$ I.D. $30 \mathrm{~m} \times 0.25 \mathrm{~mm}$ with 0.25 $\mu \mathrm{m}$ film thickness (Supelco, Schnelldorf, Germany), at following temperature program: $100{ }^{\circ} \mathrm{C} \mathrm{K}$ hold for $5 \mathrm{~min}$, rise up to $120^{\circ} \mathrm{C}$ at rate of $5{ }^{\circ} \mathrm{C} / \mathrm{min}$ and hold for $11 \mathrm{~min}$. Helium was used as carrier gas. Temperature of injector and detector were maintained at $220^{\circ} \mathrm{C}$ and $250{ }^{\circ} \mathrm{C}$, respectively.

The enantiomers of the $(R, S)$-1-phenylethanol and of the product $(R, S)$-1-phenylethyl acetate were baseline separated in the GC analysis. The conversion $(X)$ was calculated by applying the below mentioned equation:

$$
X=\frac{e e_{R}}{e e_{R}+e e_{P}} \times 100
$$

with 


$$
\begin{gathered}
e e_{R}=\frac{[(R)-1-\text { phenylethanol }]-[(S)-1-\text { phenylethanol }]}{[(R)-1-\text { phenylethanol }]+[(S)-1-\text { phenylethanol }]} \\
e e_{P}=\frac{[(R)-1-\text { phenylethylacetate }]-[(S)-1-\text { phenylethylacetate }]}{[(R)-1-\text { phenylethylacetate }]+[(S)-1-\text { phenylethylacetate }]}
\end{gathered}
$$

where square brackets represent concentration of defined substrate or product.

All samples were analyzed by GC at least twice. The relative deviation was evaluated to be within $\pm 1 \%$.

\section{Transesterification of $(R, S)-1$-phenylethanol in ILs and in $\mathrm{SC} \mathrm{CO}_{2} / \mathrm{IL}$ two- phase systems}

It is well known that not all ILs are suitable for biocatalysis. ILs containing tetrafluoroborate $\left[\mathrm{BF}_{4}\right]^{-}$, hexafluorophosphate $\left[\mathrm{PF}_{6}\right]^{-}$and bis[(trifluoromethyl)sulfonyl]amide $\left[\mathrm{NTf}_{2}\right]^{-}$anions enabled good enzymatic activities, but in ILs containing chloride $[\mathrm{Cl}]^{-}$, nitrate $\left[\mathrm{NO}_{3}\right]^{-}$, trifluoroacetate $\left[\mathrm{CF}_{3} \mathrm{CO}_{2}\right]^{-}$or acetate $\left[\mathrm{CH}_{3} \mathrm{CO}_{2}\right]^{-}$anions the activity of the enzymes was observed to decrease (Kaar et al., 2003). Of course, also other parameters, such as polarity and viscosity of ILs affected enzyme activity in ILs, as well, because they can affect both the enzyme activity and mass-transfer limitations, respectively (Lozano et al., 2001).

The influence of three different ILs, based on the $N, N^{\prime}$-dialkylimidazolium cations associated with mononuclear anions, such as $\left[\mathrm{BF}_{4}\right]^{-},\left[\mathrm{PF}_{6}\right]^{-}$and $\left[\mathrm{NTf}_{2}\right]^{-}$, on acylation of $(R, S)-$ 1-phenylethanol with vinyl acetate, was studied. Reactions were performed in a batch stirred-tank reactor at $40{ }^{\circ} \mathrm{C}$ and atmospheric pressure. Equimolar ratio of $(R, S)-1-$ phenylethanol/vinyl acetate was used. The influence of assayed ILs on conversion of (R)-1phenylethanol to $(R)-1$-phenylethyl acetate after $5 \mathrm{~h}$ is presented in Fig. 2.

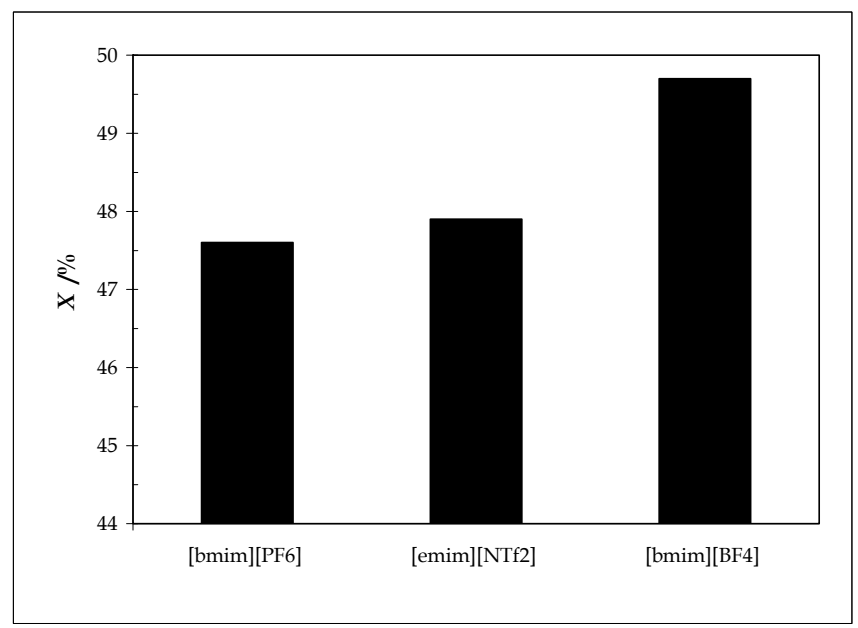

Fig. 2. Influence of three different ILs ([bmim] $\left[\mathrm{PF}_{6}\right]$, $[\mathrm{bmim}]\left[\mathrm{BF}_{4}\right]$, and $\left.[\mathrm{emim}]\left[\mathrm{NTf}_{2}\right]\right)$ on acylation of $(R, S)-1$-phenylethanol with vinyl acetate after $5 \mathrm{~h}$ of reaction performance. Reaction conditions: $c((R, S)-1$-phenylethanol $)=5 \mathrm{mmol}, c$ (vinyl acetate $)=5 \mathrm{mmol}$, $c(\mathrm{ILs})=5 \mathrm{mmol}, m$ (immobilized CALB) $=100 \mathrm{mg}, T=40^{\circ} \mathrm{C}, n=600 \mathrm{rpm}$. 
The difference in conversion of (R)-1-phenylethanol to $(R)$-1-phenylethyl acetate, obtained after $5 \mathrm{~h}$, when the reaction was performed in $[\mathrm{emim}]\left[\mathrm{NTf}_{2}\right]$ and $[\mathrm{bmim}]\left[\mathrm{PF}_{6}\right]$, was very small. Obtained conversions, performed in $[\mathrm{bmim}]\left[\mathrm{PF}_{6}\right]$ and in $[\mathrm{emim}]\left[\mathrm{NTf}_{2}\right]$, were $47.6 \%$ and $47.9 \%$, respectively. However, the highest conversion for the reaction $(49.7 \%)$ after $5 \mathrm{~h}$ of reaction performance was obtained in hydrophilic IL $[\mathrm{bmim}]\left[\mathrm{BF}_{4}\right]$. The assayed ILs, [bmim] $\left[\mathrm{BF}_{4}\right],[\mathrm{bmim}]\left[\mathrm{PF}_{6}\right]$ and $[\mathrm{emim}]\left[\mathrm{NTf}_{2}\right]$ with $\log P$ values $-2.44,-2.38$ and -1.18 (Kaar et al., 2003; Ulbert et al., 2004; Zhao et al., 2008), respectively, proved to be adequate reaction media for lipase-catalyzed acylation of $(R, S)$-1-phenylethanol with vinyl acetate.

Enzyme activity increased with the decrease in $\log P$ values of ILs and the highest enzyme activity was observed in $[\mathrm{bmim}]\left[\mathrm{BF}_{4}\right]$ with $\log P$ value -2.44 . Immobilized CALB retained its activity in all assayed ILs despite the fact that ILs have low $\log P$ values (below zero), which seem to suggest that they are highly hydrophilic in nature and would likely inactivate enzymes (Yang \& Pan, 2005).

The immobilized CALB retained its activity in assayed ILs also due to their low hydrogenbond basicity of the enzyme-compatible anions. Namely, the $\left[\mathrm{BF}_{4}\right]^{-}$spreads its negative charge over four fluorine atoms, the $\left[\mathrm{PF}_{6}\right]^{-}$over six fluorine atoms and the $\left[\mathrm{NTf}_{2}\right]^{-}$over five atoms (Park \& Kazlauskas, 2003).

ILs are much more viscous than conventional organic solvents. Using them as media for biotransformations, enzyme activity can be controlled by the viscosity of the ILs affecting the mass-transfer limitations. Therefore a lower reaction rate would be expected in an ionic liquid with higher viscosity (Yang \& Pan, 2005). Indeed, when the reaction was carried out in $[\mathrm{emim}]\left[\mathrm{NTf}_{2}\right],[\mathrm{bmim}]\left[\mathrm{BF}_{4}\right]$ and $[\mathrm{bmim}]\left[\mathrm{PF}_{6}\right]$ with viscosities of $34 \mathrm{cP}, 154 \mathrm{cP}$ and $430 \mathrm{cP}$ (Marsh et al., 2004) respectively, a reduction in the initial reaction rate was corresponding to an increase in the viscosity of the ILs (Fig. 3).

Visual observations confirmed that hydrophobic IL $[\mathrm{bmim}]\left[\mathrm{PF}_{6}\right]$ formed a layer around the enzyme and this could be considered as being included into the media. Because of the limited contact between substrate and the active site of the lipase, lower reaction rate was obtained.

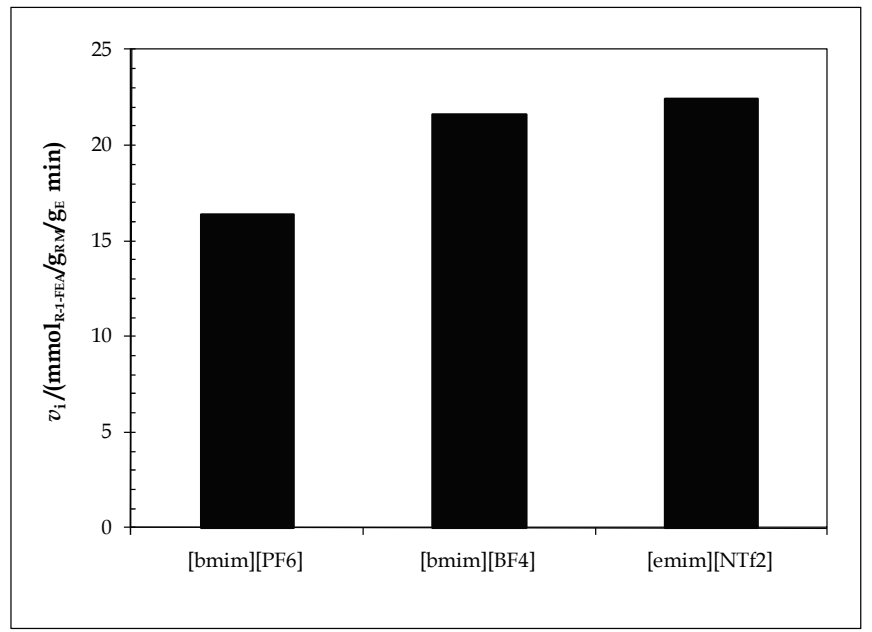

Fig. 3. Influence of different ILs ([bmim] $\left[\mathrm{PF}_{6}\right],[\mathrm{bmim}]\left[\mathrm{BF}_{4}\right]$, and $\left.[\mathrm{emim}]\left[\mathrm{NTf}_{2}\right]\right)$, on initial reaction rate. Reaction conditions: $c((R, S)-1$-phenylethanol $)=5 \mathrm{mmol}, c$ (vinyl acetate $)=5$ mmol, $c\left(\right.$ ILs) $=5 \mathrm{mmol}, m$ (immobilized CALB) $=100 \mathrm{mg}, T=40^{\circ} \mathrm{C}, n=600 \mathrm{rpm}$. 
One of the greatest advantages of the immobilized enzymes is the possibility of their reuse for a specific reaction, reducing the process costs. The possibility of enzyme reuse depends on the residual activity of the biocatalyst in the reaction medium. To study the influence of the used IL on residual activity of immobilized CALB, this was reused for transesterification of $(R)-1$-phenylethanol in $[\mathrm{bmim}]\left[\mathrm{BF}_{4}\right]$ for several reaction cycles.

After each reaction cycle, which lasted for $5 \mathrm{~h}$, the biocatalyst was regenerated by filtration and washing with acetone. Changes in the conversion of $(R)-1$-phenylethanol after each reaction cycle in $[\mathrm{bmim}]\left[\mathrm{BF}_{4}\right]$ are presented in Fig. 4. Significant changes in the conversion after each reaction cycle were observed. Conversion, obtained after $5 \mathrm{~h}$, was after $1^{\text {st }}$ reaction cycle $50 \%$, while after $2^{\text {nd }}$ one it was half of this value and after $5^{\text {th }}$ reaction cycle it was only $3.2 \%$.

To overcome the problem of enzyme inactivation, another IL should be used as a reaction medium; e.g. Schöfer et al. (Schöfer et al., 2001) reported of only 10 \% reduction of enzyme activity of immobilized CALB per reaction cycle in [bmim][ $\left.\mathrm{NTf}_{2}\right]$.

To use the benefits of two unconventional reaction media, transetserification of $(R, S)-1$ -

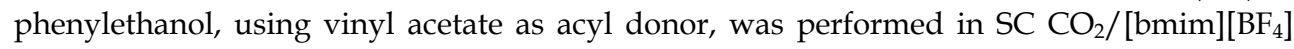
system. CALB was used to catalyze the reaction. At first, the effect of $[\mathrm{bmim}]\left[\mathrm{BF}_{4}\right]$ concentration on lipase activity was studied. IL concentrations were varied between $0 \mathrm{mmol}$ to $50 \mathrm{mmol}$, with molar ratio of substrates, $(R, S)$-1-phenylethanol and vinyl acetate, of $1: 1$ at $40{ }^{\circ} \mathrm{C}$ and $10 \mathrm{MPa}$.

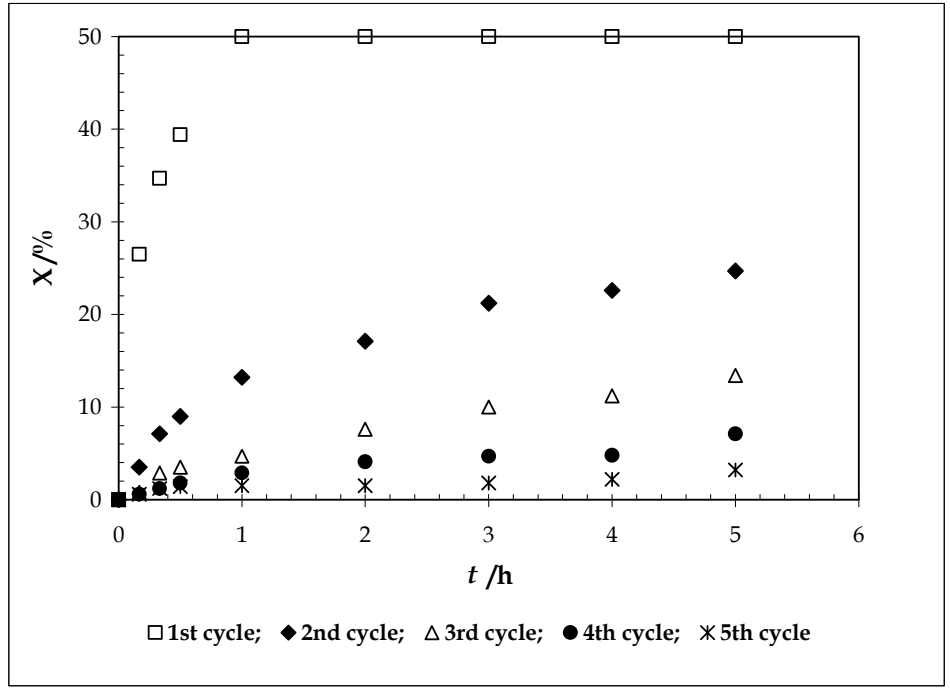

Fig. 4. Stability of immobilized CALB in $[\mathrm{bmim}]\left[\mathrm{BF}_{4}\right]$. Reaction conditions: $c((R, S)-1-$ phenylethanol $)=5 \mathrm{mmol}, c($ vinyl acetate $)=5 \mathrm{mmol}, c\left([\mathrm{bmim}]\left[\mathrm{BF}_{4}\right]\right)=5 \mathrm{mmol}, w$ (immobilized CALB; $\mathrm{w} / \mathrm{w}$ of substrates) $=20 \%, T=40^{\circ} \mathrm{C}, n=600 \mathrm{rpm}$.

Using both solvents, $\mathrm{SC} \mathrm{CO}$ and $[\mathrm{bmim}]\left[\mathrm{BF}_{4}\right]$, the reaction rate increased with the increase of IL concentration. The best results were obtained when the highest amount of [bmim] $\left[\mathrm{BF}_{4}\right]$ (50 $\mathrm{mmol}$ ) was used for the transesterification reaction. This is in agreement with the results 
obtained at atmospheric pressure which showed that by increasing the IL concentration, the conversion was enhanced (Habulin \& Knez, 2009).

Performing the reaction in the system without $[\mathrm{bmim}]\left[\mathrm{BF}_{4}\right]$, which means only in $\mathrm{SC}^{\mathrm{CO}_{2}}$, the highest CALB activity was observed. After $2 \mathrm{~h}$ of reaction performance $50 \%$ conversion was obtained. From Table 1 it is obvious that the conversion decreased drastically when [bmim $]\left[\mathrm{BF}_{4}\right]$ was added into the reaction mixture. This could be related to the presence of external mass transfer limitations, since the reaction was performed in a two-phase system with CALB particles, instead of in one-phase system with CALB particles, as in the case when the reaction was performed only in $\mathrm{SC} \mathrm{CO}_{2}$, without $[\mathrm{bmim}]\left[\mathrm{BF}_{4}\right]$.

\begin{tabular}{ccc}
\hline \multirow{2}{*}{$\mathcal{C}_{\text {[bmim][BF4] }} / \mathrm{mmol}$} & \multicolumn{2}{c}{$\mathrm{m} / \%$} \\
\cline { 2 - 3 } & $2 \mathrm{~h}$ & $8 \mathrm{~h}$ \\
\hline 0.0 & 50.0 & 50.0 \\
12.5 & 27.0 & 45.0 \\
25.0 & 24.9 & 48.9 \\
50.0 & 35.1 & 50.0 \\
\hline
\end{tabular}

Table 1. Impact of different $[\mathrm{bmim}]\left[\mathrm{BF}_{4}\right]$ concentrations on conversion of transesterification of $(R, S)$-1-phenylethanol in two-phase system SC CO $2 /$ IL after $2 \mathrm{~h}$ and $8 \mathrm{~h}$ of reaction.

In this case CALB particles were suspended in $\left[\mathrm{bmim}^{2}\left[\mathrm{BF}_{4}\right]\right.$ phase, while the substrates were in the supercritical phase. The substrate molecules had to be transferred from $\mathrm{SC} \mathrm{CO}_{2}$ phase to IL phase towards CALB particles first and secondly, products had to be transferred back to $\mathrm{SC} \mathrm{CO}_{2}$ phase.

This thesis could be proved by visual observation of the system. Fig. 5 shows the changes of the phase behaviour for $(R, S)$-1-phenylethanol/vinyl acetate/SC $\mathrm{CO}_{2} /[\mathrm{bmim}]\left[\mathrm{BF}_{4}\right]$ system when the pressure was increased from $0 \mathrm{MPa}$ (without $\mathrm{SC} \mathrm{CO}_{2}$ ) to $10 \mathrm{MPa}$ at $40^{\circ} \mathrm{C}$.

Since $\mathrm{SC} \mathrm{CO}_{2}$ dissolves quite well in ionic liquids, but ionic liquids do not dissolve in carbon dioxide (Olivier-Bourbigou \& Magna, 2002) it was expected that two-phase system with CALB particles would be obtained when the reaction was carried out in $\mathrm{SC}^{\mathrm{CO}} /[\mathrm{bmim}]\left[\mathrm{BF}_{4}\right]$ at 40 ${ }^{\circ} \mathrm{C}$ and $10 \mathrm{MPa}$. Indeed, liquid reaction bulk (solution of $(R, S)-1$-phenylethanol and vinyl acetate in $[\mathrm{bmim}]\left[\mathrm{BF}_{4}\right]$ ) at $0 \mathrm{MPa}$ (one phase system) with CALB particles was with addition of $\mathrm{CO}_{2}$ transformed to a two-phase system with CALB particles (Fig. 5).

Lower phase (catalytic phase) was rich with $\left[\mathrm{bmim}^{\mathrm{m}}\right]\left[\mathrm{BF}_{4}\right]$, while the upper phase was rich with $\mathrm{CO}_{2}$ and substrates.

CALB particles were suspended in the lower phase where the reaction took place. When the pressure achieved $10 \mathrm{MPa}$, the stirring of reaction mixture was started.

Enhanced transfer of substrates from upper phase through $[\mathrm{bmim}]\left[\mathrm{BF}_{4}\right]$ to active sites of the enzyme where the reaction took place and later the transfer of formed products from [bmim $]\left[\mathrm{BF}_{4}\right]$ phase to $\mathrm{SC} \mathrm{CO}_{2}$ phase was enabled.

Varying the concentration of $[\mathrm{bmim}]\left[\mathrm{BF}_{4}\right]$, initial reaction rates could be enhanced, as well (Fig. 6). They were increasing with increased IL concentration. Since ILs are good solvents for many organic compounds (Sheldon, 2001), higher IL concentration in the reaction mixture could cause higher solubility of substrates (Habulin \& Knez, 2009) and consecutively higher conversion and initial reaction rate were obtained. 


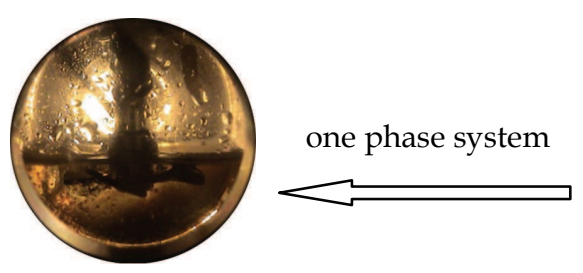

$T=40{ }^{\circ} \mathrm{C} ; p=0 \mathrm{MPa}$

$(R, S)$-1- phenylethanol and vinyl acetate/[ $\mathrm{bmim}]\left[\mathrm{BF}_{4}\right]$
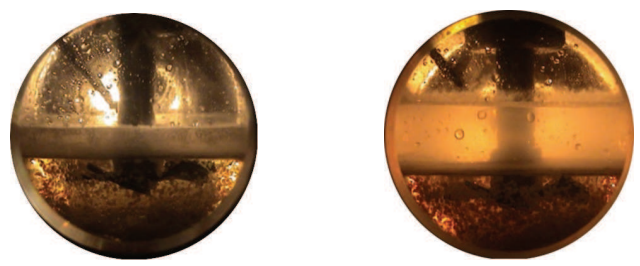

phase transition from one to two phase system

$$
T=40^{\circ} \mathrm{C} ; p=5 \mathrm{MPa}
$$$$
T=40{ }^{\circ} \mathrm{C} ; p=8 \mathrm{MPa}
$$

$(R, S)$-1- phenylethanol and vinyl acetate/ $\mathrm{SC} \mathrm{CO}_{2} /\left[\mathrm{bmim}_{[}\right]\left[\mathrm{BF}_{4}\right]$

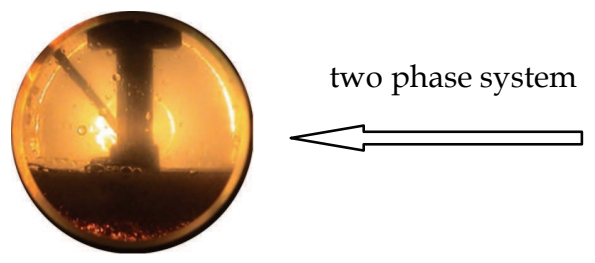

$$
T=40^{\circ} \mathrm{C} ; p=10 \mathrm{MPa}
$$

$(R, S)-1$ - phenylethanol and vinyl acetate/SC $\mathrm{CO}_{2} /[\mathrm{bmim}]\left[\mathrm{BF}_{4}\right]$

Fig. 5. Phase transitions for the system $(R, S)$-1-phenylethanol and vinyl acetate/SC $\mathrm{CO} 2 /[\mathrm{bmim}][\mathrm{BF} 4]$ with CALB particles at different pressures. 


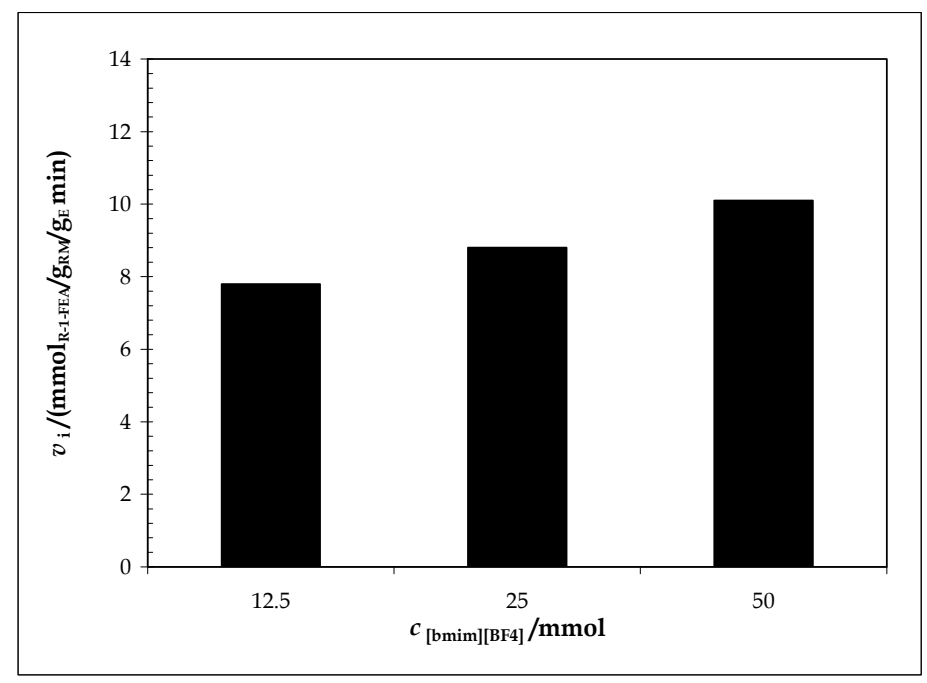

Fig. 6. Influence of different $[\mathrm{bmim}]\left[\mathrm{BF}_{4}\right]$ concentrations on initial reaction rate of $(R, S)-1$ phenylethanol transesterification in $\mathrm{SC} \mathrm{CO}_{2}$. Reaction parameters: $c((R, S)-1$-phenylethanol) $=25 \mathrm{mmol}, c$ (vinyl acetate) $=25 \mathrm{mmol}, m$ (immobilized CALB) $=0.54 \mathrm{~g}, \mathrm{~T}=40^{\circ} \mathrm{C}, p=10$ $\mathrm{MPa}, n=600 \mathrm{rpm}$.

\section{Outlook}

According to a recent review work on biocatalysis in ILs, factors such as polarity and nucleophilicity of the anion, $\mathrm{pH}$, purity of the IL and water content, have a major effect on the activity, the stability and the solubility of enzymes in these non-conventional media (van Rantwijk and Sheldon, 2007). The influence of IL concentration on the CALB activity was found to be a determining factor for the performance of the $(R, S)$-1-phenylethanol kinetic resolution at atmospheric pressure, as well as in $\mathrm{SC} \mathrm{CO}_{2} /[\mathrm{bmim}]\left[\mathrm{BF}_{4}\right]$ system. Biocatalysis with CALB, which is an excellent chiral biocatalyst for the stereo-selective acylation of racemic alcohols, gave very high kinetic resolution $(R)$-enantiomer yields and selectivity.

The unique properties of ILs to carry out biotransformations in nonaqueous environments open up new opportunities to develop green industrial processes. However, despite of opportunities afforded by ILs in biocatalysis, before the industrial-scale application of ILs in biotransformation will be feasible, several necessary steps need to be done. First, more attention should be given to synthesis of ILs, especially to new "clean" synthesis methods. The synthesis of safer ILs from natural materials (e.g. carbohydrates, proteins, lipids, and their derivatives) is in the process of development and will provide benefits for the IL industry as well as for the food industry. Therefore, techniques together with corresponding facilities for large-scale production of ILs have to be developed, because the number of ILs presently on the market is still limited (Moniruzzaman et al., 2010). The next problem presents separation of the product from IL. Large scale separation of products from ILs and recovery as well as reuse of ILs represent one of the key technologies that limits the extensive applications of ILs (Kahveci et al., 2009). 
One of the possibilities is use of biphasic systems IL/SCF. Lozano et al. proposed two-phase systems IL/SC $\mathrm{CO}_{2}$ as the first approach to integral green bioprocesses in non-aqueous media, where both the biocatalytic and extraction steps are coupled in an environmentally benign and efficient reaction/separation process (Lozano et al., 2007c).

\section{References}

Anderson, J.L., Ding, J., Welton, T. \& Armstrong, D.W. (2002). Characterizing ionic liquids on the basis of multiple solvation interactions, J. Am. Chem. Soc., 124(47): 1424714254.

Arai, S., Nakashima, K., Tanino, T., Ogino, C., Kondo, A. \& Fukuda, H. (2010). Production of biodiesel fuel from soybean oil catalyzed by fungus whole-cell biocatalysts in ionic liquids, Enzyme Microb. Tech., 46(1): 51-55.

Blanchard, L.A. \& Brennecke, J.F. (2001). Recovery of organic products from ionic liquids using supercritical carbon dioxide, Ind. Eng. Chem. Res., 40(1): 287-292.

Blanchard, L.A., Gu, Z. \& Brennecke, J.F. (2001). High-pressure phase behavior of ionic liquid/ $\mathrm{CO}_{2}$ systems, J. Phys. Chem. B, 105(12): 2437-2444.

Bräutigam, S., Dennewald, D., Schürmann, M., Lutje-Spelberg, J., Pitner, W.R. \& WeusterBotz, D. (2009). Whole-cell biocatalysis: Evaluation of new hydrophobic ionic liquids for efficient asymmetric reduction of prochiral ketones, Enzyme Microb. Tech., 45(4): 310-316.

Brennecke, J.F. \& Maginn, E.J. (2001). Ionic Liquids: Innovative Fluids for Chemical Processing, AIChE Journal, 47(11): 2384-2389.

Contesini, F.J. \& Carvalho, P.D. (2006). Esterification of $(R, S)$-ibuprofen by native and commercial lipases in a two-phase system containing ionic liquids, TetrahedronAsymmetr., 17(14): 2069-2073.

De Diego, T., Lozano, P., Gmough, S., Vaultier, M. \& Iborra, J.L. (2005). Understanding structure - stability relationships of Candida antarctica lipase B in ionic liquids, Biomacromolecules, 6(3): 1457-1464.

De los Rios, A.P., Hernandez-Fernandez, F.J., Gomez, D., Rubio, M., Tomas-Alonso F. \& Villora, G. (2007). Understanding the chemical reaction and mass-transfer phenomena in a recirculating enzymatic membrane reactor for green ester synthesis in ionic liquid/supercritical carbon dioxide biphasic systems, J. Supercrit. Fluid., 43(2): 303-309.

Eckstein, M., Wasserscheid, P. \& Kragl, U. (2002). Enhanced enantioselectivity of lipase from Pseudomonas sp. at high temperatures and fixed water activity in the ionic liquid 1butyl-3-methyl bis((trifluoromethyl)sulfonyl)amide, Biotechnol. Lett., 24(10): 763767.

Fan, Y. \& Qian, J. (2010). Lipase catalysis in ionic liquids/supercritical carbon dioxide and its applications, J. Mol. Catal. B: Enzym., 66(1-2): 1-7.

Faber, K. (2000). Biotransformations in Organic Chemistry, Springer-Verlag, Berlin.

Garcia, S., Lourenco, N.M.T., Lousa, D., Sequeira, A.F., Mimoso, P., Cabral, J.M.S., Afonso C.A.M. \& Barreiros, S. (2004). A comparative study of biocatalysis in nonconventional solvents: Ionic liquids, supercritical fluids and organic media, Green Chem., 6(9): 466-470. 
Goswami, A. \& Goswami, J. (2005). DMSO-triggered enhancement of enantioselectivity in Novozyme[435]-catalyzed transesterification of chiral 1-phenylethanols, Tetrahedron Lett., 46(25): 4411-4413.

Habulin, M. \& Knez, Ž. (2001). Pressure stability of lipases and their use in different systems, Acta Chim. Slov., 48(4): 521-532.

Habulin, M., Primožič, M. \& Knez, Ž. (2007a). Supercritical fluids as solvents for enzymatic reactions, Acta Chim. Slov., 54(4): 667-677.

Habulin, M., Šabeder, S., Paljevac, M., Primožič, M. \& Knez, Ž. (2007b). Lipase-catalyzed esterification of citronellol with lauric acid in supercritical carbon dioxide/cosolvent media, J. Supercrit. Fluid., 43(2): 199-203.

Habulin, M. \& Knez, Ž. (2009). Optimization of $(R, S)-1$-phenylethanol kinetic resolution over Candida antarctica lipase B in ionic liquids, J. Mol. Catal. B: Enzym., 58(1-4): 24-28.

Hernández, F.J., de los Ríos, A.P., Gómez, D., Rubio, M. \& Víllora, G. (2006). A new recirculating enzymatic membrane reactor for ester synthesis in ionic liquid/supercritical carbon dioxide biphasic systems, Appl. Catal. B: Environ., 67(12): $121-126$.

Hernández-Fernandez, F.J., de los Ríos, A.P., Rubio, M., Gómez, D. \& Víllora, G. (2007). Enhancement of activity and selectivity in lipase-catalyzed transesterification in ionic liquids by the use of additives, J. Chem. Technol. Biotechnol., 82(19): 882-887.

Hobbs, H.R. \& Thomas, N.R. (2007). Biocatalysis in Supercritical Fluids, in Fluorous Solvents, and under Solvent-Free Conditions, Chem. Rev., 107(6): 2786-2820.

Jessop, P.G \& Leitner, W. (1999). Chemical synthesis using supercritical fluids, Wiley-VCH, Weinheim.

Kaar, J.L., Jesionowski, A.M., Berberich, J.A., Moulton, R. \& Russell, A.J. (2003). Impact of ionic liquid physical properties on lipase activity and stability, J. Am. Chem. Soc., 125(14): 4125-4131.

Kahveci, D., Guo, Z., Özçelik, B. \& Xu, X. (2009). Lipase-catalyzed glycerolysis in ionic liquids directed towards diglyceride synthesis, Process Biochem., 44(12): 1358-1365.

Katsoura, M.H., Polydera, A.C., Tsironis, L.D., Petraki, M.P., Kostić Rajačić, S., Tselepis, A.D. \& Stamatis, H. (2009). Efficient enzymatic preparation of hydroxycinnamates in ionic liquids enhances their antioxidant effect on lipoproteins oxidative modification, New Biotechnol., 26(1/2): 83-91.

Knez, Ž. \& Habulin, M. (1992). Lipase catalysed esterification in supercritical carbon dioxide, In: Progress in Biotechnology 8, Biocatalysis in Non-Conventional Media, J. Tramper, M.H. Vermüe, and H.H. Beeftink (Eds.), pp. 401-406, Elsevier, New York.

Knez, Ž. \& Habulin, M. (2002). Compressed gases as alternative enzymatic-reaction solvents: a short review, J. Supercrit. Fluid., 23(1): 29-42.

Knez, Ž. (2009). Enzymatic reactions in dense gases, J. Supercrit. Fluid., 47(3): 357-372.

Kragl, U., Eckstein, M. \& Kaftzik, N. (2002). Enzyme catalysis in ionic liquids, Curr. Opin. Biotechnol., 13(6): 565-571.

Krishna, S.H. (2002). Developments and trends in enzyme catalysis in nonconventional media, Biotechnol. Adv., 20(3-4): 239-267.

Kurata, A., Kitamura, Y., Irie, S., Takemoto, S., Akai, Y., Hirota, Y., Fujita, T., Iwai, K., Furusawa, M. \& Kishimoto, N. (2010). Enzymatic synthesis of caffeic acid phenethyl ester analogues in ionic liquid, J. Biotechnol., 148(2-3): 133-138. 
Lewandowski, A. \& Galiński, M. (2004). Carbon-ionic liquid double-layer capacitors, J. Phys. Chem. Solids, 65(2-3): 281-286.

Liese, A., Seelbach, K.\& Wandrey, C. (2000). Industrial Biotransformations, Wiley-VCH, Weinheim.

Lou, W.Y., Zong, M.H., Liu, Y.Y. \& Wang J.F. (2006). Efficient enantioselective hydrolysis of D,L-phenylglycine methyl ester catalyzed by immobilized Candida antarctica lipase $\mathrm{B}$ in ionic liquid containing systems, J. Biotechnol., 125(1): 64-74.

Lozano, P., de Diego, T., Guegan, J.-P., Vaultier, M. \& Iborra, J.L. (2001). Stabilization of achymotrypsin by ionic liquids in transesterification reactions, Biotechnol. Bioeng., 75(5): 563-569.

Lozano, P., De Diego, T., Carrié, D., Vaultier M. \& Iborra J.L. (2002). Continuous green biocatalytic processes using ionic liquids and supercritical carbon dioxide, Chem. Commun., 7: 692-693.

Lozano, P., De Diego, T., Carrié, D., Vaultier, M. \& Iborra, J.L. (2003). Lipase catalysis in ionic liquids and supercritical carbon dioxide at $150{ }^{\circ} \mathrm{C}$, Biotechnol. Prog., 19(2): 380382.

Lozano, P., De Diego, T., Gmouh, S., Vaultier, M. \& Iborra, J.L. (2004). Criteria to design green enzymatic processes in ionic liquid/supercritical carbon dioxide systems, Biotechnol. Prog., 20(3): 661-669.

Lozano, P., de Diego, T., Larnicol, M., Vaultier, M. \& Iborra, J.L. (2006). Chemoenzymatic dynamic kinetic resolution of rac-1-phenylethanol in ionic liquids and ionic liquids/supercritical carbon dioxide systems, Biotechnol. Lett., 28(19): 1559-1565.

Lozano, P., De Diego, T., Gmouh, S., Vaultier, M. \& Iborra, J.L. (2007a). A continuous reactor for the (chemo)enzymatic dynamic kinetic resolution of rac-1-phenylethanol in ionic liquid/supercritical carbon dioxide biphasic systems, Int. J. Chem. Reactor Eng., 5: Article A53.

Lozano, P., De Diego, T., Sauer, T., Vaultier, M., Gmouh, S. \& Iborra J.L. (2007b). On the importance of the supporting Candida antarctica lipase B in material for activity of immobilized ionic liquid/hexane and ionic liquid/supercritical carbon dioxide biphasic media, J. Supercrit. Fluid., 40(1): 93-100.

Lozano, P., De Diego, T. \& Iborra J.L. (2007c). Enzymatic catalysis in ionic liquids and supercritical carbon dioxide biphasic systems, Chem. Today, 25(6): 76-79.

Lue, B.M., Guo, Z. \& Xu, X. (2010). Effect of room temperature ionic liquid structure on the enzymatic acylation of flavonoids, Process Biochem., 45(8): 1375-1382.

Marsh, K.N., Boxall, J.A. \& Lichtenthaler, R. (2004). Room temperature ionic liquids and their mixtures - a review, Fluid Phase Equilib., 219(1): 93-98.

Matsuda, T., Harada, T. \& Nakamura, K. (2005). Biocatalysis in supercritical $\mathrm{CO}_{2}$, Curr. Org. Chem., 9(3): 299-315.

Mesiano, A.J., Beckman, E.J. \& Russell, A.J. (1999). Supercritical biocatalysis, Chem. Rev., 99(2): 623-633.

Miyawaki, O. \& Tatsuno, M. (2008). Lipase-catalyzed butanolysis of triolein in ionic liquid and selective extraction of product using supercritical carbon dioxide, J. Biosci. Bioeng., 105(1): 61-64.

Moniruzzaman, M., Nakashima, K., Kamiya N. \& Goto, M. (2010). Recent advances of enzymatic reactions in ionic liquids, Biochem. Eng. J., 48(3): 295-314. 
Olivier-Bourbigou, H. \& Magna, L. (2002). Ionic liquids: Perspectives for organic and catalytic reactions, J. Mol. Catal. A.: Chem., 182-183: 419-437.

Paljevac, M., Knez, Ž. \& Habulin, M. (2009). Lipase-Catalyzed Transesterification of $(R, S)-1-$ Phenylethanol in $\mathrm{SC} \mathrm{CO}_{2}$ and in $\mathrm{SC} \mathrm{CO}_{2}$ /Ionic Liquid Systems, Acta Chim. Slov., 56(4): 815-825.

Park, S. \& Kazlauskas, R.J. (2003). Biocatalysis in ionic liquids - advantages beyond green technology, Curr. Opin. Biotechnol., 14(4): 432-437.

Randolph, T.W., Blanch, H.W., Prausnitz, J.M. \& Wilke, C.R. (1985). Enzymatic catalysis in supercritical fluid, Biotechnol. Lett., 7(5): 325-328.

Reetz, M.T., Wiesenhofer, W., Francio, G. \& Leitner, W. (2002). Biocatalysis in Ionic Liquids: Batchwise and Continuous-Flow Processes Using Supercritical Carbon Dioxide as the Mobile Phase, Chem. Commun., (9): 992-993.

Schöfer, S.H., Kaftzik, N., Wasserscheid, P. \& Kragl, U. (2001). Enzyme catalysis in ionic liquids: lipase catalysed kinetic resolution of 1-phenylethanol with improved enantioselectivity, Chem. Commun., (5): 425-426.

Sheldon, R.A. (2001). Catalytic Reactions in Ionic Liquids, Chem. Commun., (23): 2399-2407.

Sheldon, R.A. (2005). Green solvents for sustainable organic synthesis: State of the art, Green Chem., 7(5): 267-278.

Singh, M., Singh, R.S., \& Banerjee, U.C. (2010). Enantioselective transesterification of racemic phenyl ethanol and its derivatives in organic solvent and ionic liquid using Pseudomonas aeruginosa lipase, Process Biochem., 45(1): 25-29.

Suan, C.L. \& Sarmidi, M.R. (2004). Immobilised lipase-catalysed resolution of $(R, S)-1-$ phenylethanol in recirculated packed bed reactor, J. Mol. Catal. B: Enzym., 28(2-3): 111-119.

Sureshkumar, M. \& Lee, C.-K. (2009). Biocatalytic reactions in hydrophobic ionic liquids, J. Mol. Catal. B: Enzym., 60(1-2): 1-12.

Tan, Z.Y., Wu, H. \& Zong, M.H. (2007). Novozym 435-catalyzed regioselective benzoylation of 1-beta-D-arabinofuranosylcytosine in a co-solvent mixture of C(4)MIm center dot PF6 and pyridine, Biocatal. Biotransform., 25(5): 408-413.

Ulbert, O., Fráter, T., Bélafi-Bakó, K. \& Gubicza, L. (2004). Enhanced enantioselectivity of Candida rugosa lipase in ionic liquids as compared to organic solvents, J. Mol. Catal. B: Enzym., 31(1-3): 39-45.

Vafiadi, C., Topakas, E., Nahmias, V.R., Faulds, C. B. \& Christakopoulos, P. (2009). Feruloyl esterase-catalysed synthesis of glycerol sinapate using ionic liquids mixtures, J. Biotechnol., 139: 124-129.

van Rantwijk, F., Lau, R.M. \& Sheldon, R.A. (2003). Biocatalytic transformations in ionic liquids, Trends Biotechnol., 21(3): 131-138.

van Rantwijk, F. \& Sheldon, R.A. (2007). Biocatalysis in ionic liquids, Chem. Rev., 107(6): 2757-2785.

Vidya, P. \& Chadha, A. (2010). Pseudomonas cepacia lipase catalyzed esterification and transesterification of 3-(furan-2-yl) propanoic acid/ethyl ester: A comparison in ionic liquids vs hexane, J. Mol. Catal. B: Enzym., 65(1-4): 68-72.

Welton, T. (1999). Room-temperature ionic liquids. Solvents for synthesis and catalysis, Chem. Rev., 99(8): 2071-2083. 
Yang, Z. \& Pan, W. (2005). Ionic liquids: green solvents for nonaqueous biocatalysis, Enzyme Microb. Technol., 37(1): 19-28.

Zhao, H., Baker, G.A., Song, Z., Olubajo, O., Zanders, L. \& Campbell, S.M. (2008). Effect of ionic liquid properties on lipase stabilization under microwave irradiation, J. Mol. Catal. B: Enzym., 57(1-4): 149-157. 


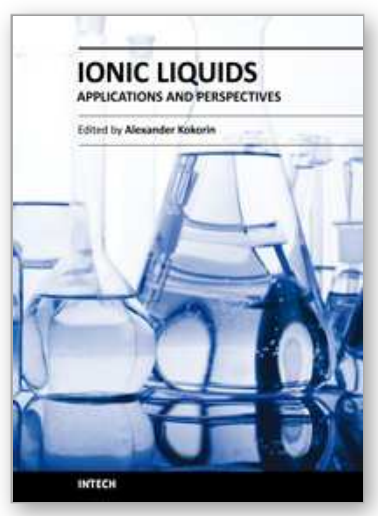

\author{
Ionic Liquids: Applications and Perspectives \\ Edited by Prof. Alexander Kokorin
}

ISBN 978-953-307-248-7

Hard cover, 674 pages

Publisher InTech

Published online 21, February, 2011

Published in print edition February, 2011

This book is the second in the series of publications in this field by this publisher, and contains a number of latest research developments on ionic liquids (ILs). This promising new area has received a lot of attention during the last 20 years. Readers will find 30 chapters collected in 6 sections on recent applications of ILs in polymer sciences, material chemistry, catalysis, nanotechnology, biotechnology and electrochemical applications. The authors of each chapter are scientists and technologists from different countries with strong expertise in their respective fields. You will be able to perceive a trend analysis and examine recent developments in different areas of ILs chemistry and technologies. The book should help in systematization of knowledges in ILs science, creation of new approaches in this field and further promotion of ILs technologies for the future.

\title{
How to reference
}

In order to correctly reference this scholarly work, feel free to copy and paste the following:

Maja Habulin, Mateja Primožič and Željko Knez (2011). Application of lonic Liquids in Biocatalysis, Ionic Liquids: Applications and Perspectives, Prof. Alexander Kokorin (Ed.), ISBN: 978-953-307-248-7, InTech, Available from: http://www.intechopen.com/books/ionic-liquids-applications-and-perspectives/application-ofionic-liquids-in-biocatalysis

\section{INTECH}

open science | open minds

\author{
InTech Europe \\ University Campus STeP Ri \\ Slavka Krautzeka 83/A \\ 51000 Rijeka, Croatia \\ Phone: +385 (51) 770447 \\ Fax: +385 (51) 686166 \\ www.intechopen.com
}

\author{
InTech China \\ Unit 405, Office Block, Hotel Equatorial Shanghai \\ No.65, Yan An Road (West), Shanghai, 200040, China \\ 中国上海市延安西路65号上海国际贵都大饭店办公楼 405 单元 \\ Phone: +86-21-62489820 \\ Fax: +86-21-62489821
}


(C) 2011 The Author(s). Licensee IntechOpen. This chapter is distributed under the terms of the Creative Commons Attribution-NonCommercialShareAlike-3.0 License, which permits use, distribution and reproduction for non-commercial purposes, provided the original is properly cited and derivative works building on this content are distributed under the same license. 